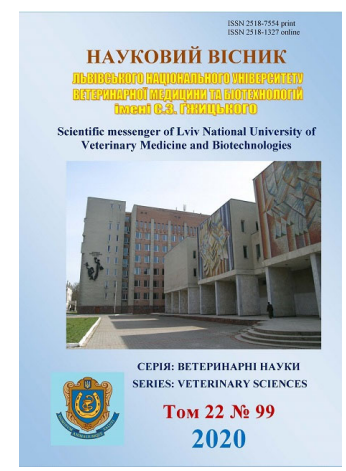

\author{
Науковий вісник Дьвівського націонадьного університету \\ ветеринарної медицини та біотехнодогій імені С.3. Гжицького. \\ Серія: Ветеринарні науки \\ Scientific Messenger of Lviv National University \\ of Veterinary Medicine and Biotechnologies. \\ Series: Veterinary sciences
}

\title{
Histological characteristics of Platelet-Rich Fibrin clots obtained under various modes of blood centrifugation
}

\author{
S. N. Shevchenko, M. V. Rublenko \\ Bila Tserkva National Agrarian University, Bila Tserkva, Ukraine
}

Article info

Received 08.09.2020

Received in revised form 08.10 .2020

Accepted 09.10.2020

Bila Tserkva National Agrarian University, pl. Soborna 8/1, Bila Tserkva, 09117 Ukraine. Tel.: +38-097-859-58-11

E-mail:

svitlana.shevchenko@btsau.edu.ua
Shevchenko, S. N., \& Rublenko, M. V. (2020). Histological characteristics of Platelet-Rich Fibrin clots obtained under various modes of blood centrifugation. Scientific Messenger of Lviv National University of Veterinary Medicine and Biotechnologies. Series: Veterinary sciences, 22(99), 84-93. doi: $10.32718 /$ nvlvet 9914

Autologous products of the first and second generation, namely platelet-rich plasma and platelet-rich fibrin, are considered promising for regenerative medicine. They differ from each other in physical properties, as well as in the way they are obtained. The key procedure of all techniques is centrifugation; changing its parameters affects the biological properties of these biomaterials. The aim of the work is to determine and histologically characterize the area of concentration cells of autologous fibrin enriched with platelets, depending on the change in centrifugation parameters. The studies were carried out on rabbits. Blood was collected and platelet-rich plasma (PRP) and platelet-rich fibrin (PRF) were obtained using different values of relative centrifugal force: $100 \mathrm{~g}, 400 \mathrm{~g}, 735 \mathrm{~g}, 906 \mathrm{~g}, 1843 \mathrm{~g}$. Due to the fact that it is impossible to determine the number of platelets in PRF clots, the counting was performed in platelet-rich plasma obtained by a single centrifugation with the corresponding parameters that were used to obtain PRF. The length of the formed clots was compared and a histological assessment of the cell composition in different layers (lower, middle and upper) was carried out. The highest platelet concentrations were observed in PRP obtained at $100 \mathrm{~g}$ and $400 \mathrm{~g}$. Application of different values of centrifugal force showed obvious differences in the formation of platelet-rich fibrin clots. After preparation of I-PRF, its volume was significantly less than that of standard PRF, and the border between erythrocytes was less distinct. During the histological examination of fibrin clots, a change in the distribution of cellular elements in different parts was found with a change in the centrifugation parameters. With an increase in the parameter of relative centrifugal force, the length of the fibrin clot significantly increases, but the concentration of platelets in it significantly decreases. That is, it was found that the most optimal value of the relative centrifugal force for obtaining platelet mass is $100 \mathrm{~g}$, which makes it possible to achieve the number of platelets greater than $800 \times 10^{9} / \mathrm{L}$.

Key words: centrifuges, fibrin, platelet mass, relative centrifugal force, blood cells.

\section{Гістологічна характеристика згустків фібрину, збагачених тромбоцитами i одержаних за різних режимів центрифугування крові}

\author{
С. М. Шевченко, М. В. Рубленко
}

Білочерківський національний аграрний університет, м. Біла Церква, Украӥна

\footnotetext{
Аутологічні продукти першого та другого покоління, а саме плазма та фібрин, збагачені тромбоцитами, вважаються перспективними для регенеративної медицини. Вони відрізняються одне від одного за фізичними властивостями, а також за способами їх одержання. Ключова прочедура усіх методик - иентрифугування, зміна його параметрів впливає на біологічні властивості зазначених біоматеріалів. Мета роботи - визначити та гістологічно охарактеризувати ділянки концентрування клітин аутологічного фібрину, збагаченого тромбоцитами, залежно від зміни параметрів центрифугування. Дослідження виконували на кролях. Відбирали кров та одержували плазму (PRP) і фібрин (PRF), збагачені тромбоцитами, використовуючи різні величини відносної
} 
відиентрової сили: 100 g, 400 g, 735 g, 906 g, 1843 g. У зв'язку з тим, щуо у згустках РRF визначити кількість тромбоцитів неможливо, підрахунок проводили у плазмі, збагаченій тромбоцитами, отриманій шляхом одноразового центрифугування з відповідними параметрами, які використали для одержання PRF. Порівнювали довжину сформованих згустків та проводили гістологічну оцінку клітинного складу в різних їх шарах (нижньому, середньому і верхньому). Найвищі концентрації тромбоцитів виявляли у РRР, одержаній за $100 \mathrm{~g} \mathrm{ma} 400 \mathrm{~g}$. Застосування різних величин відиентрової сили показали очевидні відмінності у формуванні згустків фібрину, збагачених тромбочитами. Після приготування I-PRF його об'єм був значно меншим, порівняно зі стандартним РRF, а межа між еритрочитами - менш чіткою. Під час гістологічного дослідження фібринових згустків виявили зміну розподілу клітинних елементів у різних частинах за зміни параметрів цуентрифугування. При підвищенні відносної відиентрової сили суттєво збільшується довжина фібринового згустку, але суттєво зменшується в ньому концентрація тромбоцитів. Тобто встановлено, щзо найбільш оптимальною величиною відносної відцентрової сили для отримання тромбоцитарної маси є 100 g, щуо дозволяє досягти кількості тромбочуитів, більшої за $800 \times 10^{9} /$.

Ключові слова: цүентрифуги, фібрин, тромбоцитарні маси, відносна відцентрова сила, клітини крові.

\section{Ветуп}

Широковживане нині поняття регенеративної медицини та іï розвиток зумовлені лавиноподібною розробкою новітніх біотехнологій генної і клітинної терапії та інжинірінга тканин, що забезпечують неповну (субституцію) та повну (реституцію) регенерацію тканин і органів (Gillman et al., 2020; Davenport Huyer et al., 2020).

При цьому одним із пріоритетних напрямів у регенеративній медицині $€$ застосування біотехнологій для прискорення процесів регенерації за пошкодження кісток і м'яких тканин. Зокрема, це використання тромбоцитарних технологій для лікування патологій опорно-рухового апарату та прискорення регенерації тканин (Dohan Ehrenfest et al., 2009; Bielecki \& Dohan Ehrenfest, 2012; Rublenko et al., 2014).

На сучасному етапі практикують застосування декількох поколінь тромбоцитарних концентратів, які вважаються перспективними для регенеративної медицини. До першого зараховують плазму, збагачену тромбоцитами (PRP - Platelet-Rich Plasma) (Dohan et al., 2006; Douglas et al., 2018; Shevchenko et al., 2019). Удосконалення технологій отримання речовин, концентруючих тромбоцити, сприяло розвитку другого покоління цих біоматеріалів, а саме фібрину, збагаченого тромбоцитами (PRF - Platelet-Rich Fibrin) (Dohan Ehrenfest et al., 2012; Tina Roshini et al., 2019; Chernyshenko et al., 2019). Аутологічні продукти першого та другого покоління відрізняються один від одного за фізичними властивостями, а також за способами їх одержання, в тому числі за кількістю ступенів центрифугування (Pazzini et al., 2016; Khalaf \& Salih, 2018; Yaltirik et al., 2018). Плазму, збагачену тромбоцитами, виготовляють шляхом відбору зразка крові з різними антикоагулянтами та наступним одночи двоступеневим центрифугуванням, у результаті чого отримують очищену плазму, збагачену тромбоцитами, або плазму, збагачену лейкоцитами та тромбоцитами. Проте присутність антикоагулянтів і необхідність додавання різних речовин як активаторів тромбоцитів можуть викликати негативні реакції організму як неаутологічні продукти (Franklin et al., 2017; Chicharro et al., 2018; Etulain, 2018; Maia et al., 2019). 3 огляду на це, до переваг PRF зараховують нескладну та швидку техніку його одержання, відсутність необхідності додавання сторонніх речовин, біохімічних обробок, імунних реакцій, передачі інфекційних захворювань, а також поступовий екстрацелю- лярний вихід із тромбоцитів факторів росту протягом семи діб (Kiran et al., 2011; Ayswaria et al., 2018). У зв'язку з цим багато дослідників зосереджують свою увагу саме на фібрині, збагаченому тромбоцитами.

До складу PRF входять 97 \% тромбоцитів та 50 \% (Kiran et al., 2011; Kossev \& Sokolov, 2015; Yaltirik et al., 2018) лейкоцитів, які розміщені у тривимірному структурованому фібриновому каркасі та здатні впливати на проліферацію і міграцію інших клітин, що беруть участь у репаративних процесах (Choukroun \& Ghanaati, 2018).

PRF вважається достатньо ефективним у використанні як ізольовано, так і в комбінації з різноманітними матеріалами (Zhang et al., 2012). Його застосування пропонують 3 метою стимуляції регенерації різних тканин, яка прискорюється за рахунок екскреції активованими альфа-гранулами тромбоцитів факторів росту: тромбоцитарний фактор росту (PDGF), трансформуючий фактор росту (TGF- $\beta 1)$, судинний ендотеліальний фактор росту (VEGF), інсуліноподібний фактор росту (IGF-1) та інші. Вони володіють індуктивними властивостями щодо клітин різних тканин організму (Oryan et al., 2014; De Pascale et al., 2015; Arora \& Agnihotri, 2017).

Водночас неповна характеристика протоколів приготування PRF, відсутність чіткої їх класифікації і стандартизації значно ускладнює (навіть порівняно 3 PRP, у якій можна підрахувати кількість клітин (de Almeida et al., 2018), систематизацію та порівняння існуючих результатів досліджень, що зумовлює дискусію щодо біолікувальної ефективності кожного фактора росту за певних нозологічних форм патології (Bansal et al., 2017).

Дотепер розроблена значна кількість методик приготування фібрину, збагаченого тромбоцитами, 3 використанням комерційно доступних автоматичних приладів чи за допомогою лабораторних центрифуг, що зумовило виникнення безлічі форм фібрину, збагаченого тромбоцитами: P-PRF (Pure platelet-rich fibrin), L-PRF (Leukocyte and platelet-rich fibrin), APRF (Advanced platelet-rich fibrin), I-PRF (Injectable platelet-rich fibrin), T-PRF (Titanium platelet-rich fibrin) (Yaltirik et al., 2018). Їхня основна відмінність полягає у зміні часу центрифугування, його швидкості та матеріалах пробірок, у які відбирають зразки крові (Peck et al., 2016; Choukroun \& Ghanaati, 2018).

Ключова процедура усіх методик - центрифугування, параметри якого впливають на біологічні властивості зазначених біоматеріалів. Здебільшого фіб- 
рин, збагачений тромбоцитами, застосовують у гуманній медицині, переважно в стоматології та щелепо-лицевій хірургії. При цьому відбирають кров об'ємом не менше 10 мл та центрифугують 8-12 хв. Проте I-PRF (ін'єкційний) готують за низької відносної відцентрової сили центрифугування - у межах 100 g протягом 2-3 хв, у результаті чого утворюється рідка фракція, що поступово протягом декількох хвилин полімеризується. Властивості цих біологічних продуктів відрізняються, а тому по-різному впливають на процеси регенерації (Wang et al., 2017; Choukroun \& Ghanaati, 2018; Thanasrisuebwong et al., 2019). При цьому об’єктивність їх оцінки ускладнена недостатньою інформативністю.

У ветеринарній медицині постає необхідність модифікації методів підготовки тромбоцитарних мас у зв'язку з обмеженим об'ємом крові у дрібних тварин (собаки малих порід та коти), оскільки нерідко відбір 10 мл за певних умов може бути критичним для здоров'я пацієнтів (Ghanaati et al., 2018).

Ще одна причина необхідної модифікації протоколів - використання центрифуг з різними радіусами роторів, які за однакової швидкості обертання приладів мають різні величини відносної відцентрової сили та відповідно ступінь розподілу клітин у згустку PRF. Центрифуги з фіксованим кутом та горизонтальні теж можуть мати вплив на розподіл клітин у згустку (Ghanaati et al., 2018; Chernyshenko et al., 2019). Bсе це може впливати на клінічну ефективність фібрину, збагаченого тромбоцитами.

Мета роботи - визначити та гістологічно охарактеризувати ділянки концентрування клітин аутологічного фібрину, збагаченого тромбоцитами, залежно від зміни параметрів центрифугування.

\section{Матеріал і методи досліджень}

Дослідження виконувалися на базі кафедри хірургії та хвороб дрібних домашніх тварин Білоцерківського НАУ відповідно до закону України "Про захист тварин від жорстокого поводження” від 28.03.2006 р., правил Свропейської конвенції захисту хребетних тварин, які використовуються в експериментальних та інших наукових цілях від 13.11.1987 р., та Наказу МОН № 416/20729 від 16 березня 2012 р. "Про затвердження Порядку проведення науковими установами дослідів, експериментів на тваринах". Схему проведення досліджень було затверджено Етичним комітетом БНАУ протокол № 1 від 23 січня 2019.

Для дослідження використовували клінічно здорових кролів 3 масою тіла 2,5 кг, яких утримували у віварії Білоцерківського НАУ в індивідуальних клітках. Вони мали необмежений доступ до води, годівлю забезпечували комбікормом для кролів із розрахунку 200 г на одну голову за добу. Напередодні дослідження провели морфологічне дослідження крові за загальноприйнятими методиками для виключення можливих відхилень у коливанні кількості еритроцитів, лейкоцитів і тромбоцитів. Кількість останніх становила $208,2 \pm 7,78 \times 10^{9} /$ л.

У зв'язку з тим, що у згустках PRF підрахувати кількість тромбоцитів неможливо, попередньо приготували плазму, збагачену тромбоцитами, шляхом одноразового центрифугування $з$ відповідними величинами відносної відцентрової сили, які використали для одержання PRF (рис 1.).

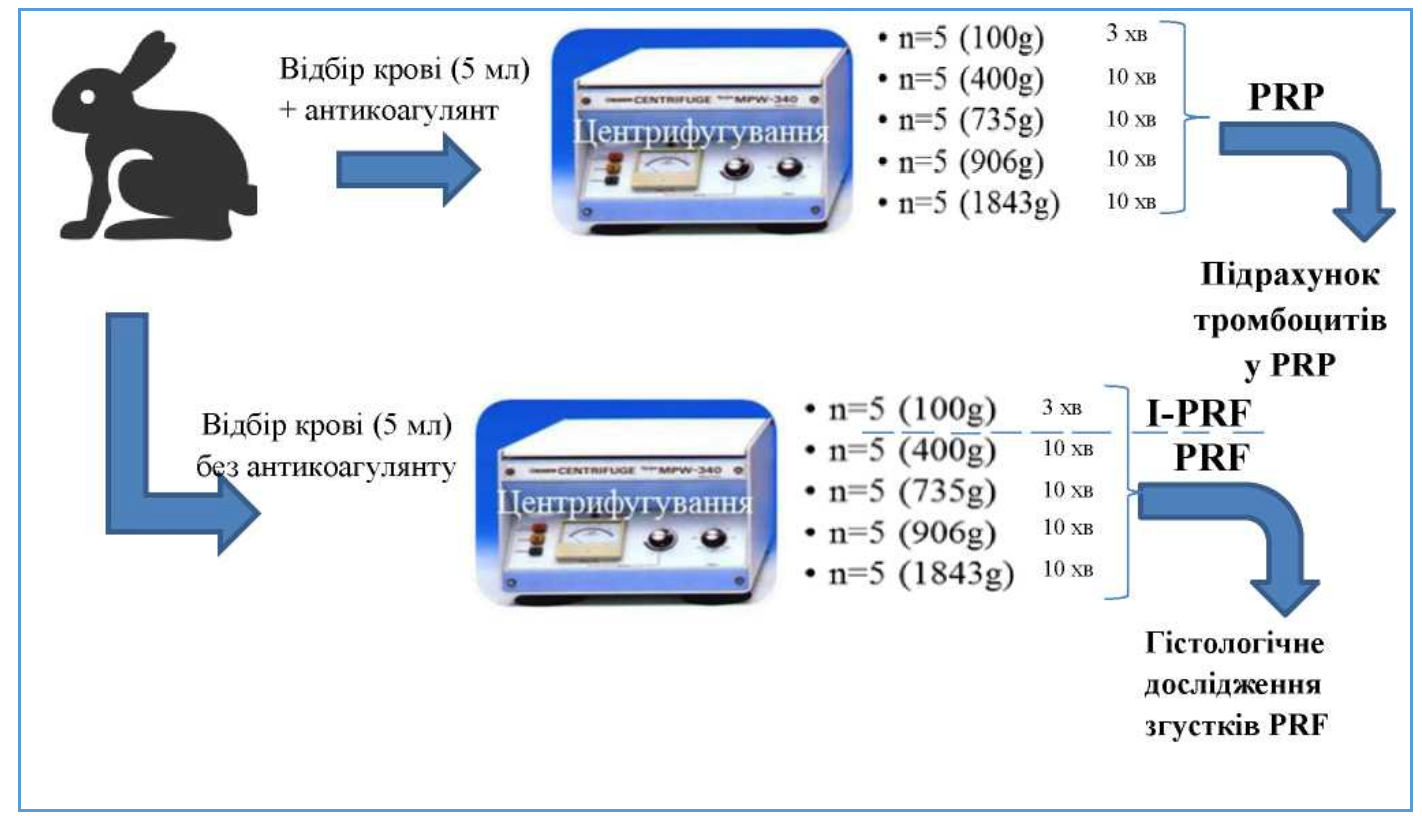

Рис. 1. Одержання плазми та фібрину, збагачених тромбоцитами

У кролів $(\mathrm{n}=25)$ з яремної вени відбирали кров об'ємом 5 мл, використовуючи як антикоагулянт 3,8 \% цитрат натрію. Центрифугування проводили за відносної відцентрової сили 100 g протягом 3 хв, а за
400, 735, 906 та $1843 \mathrm{~g}-10$ хв. Після розподілу крові на фракції (у нижній частині містилися еритроцити, над ними розміщувався лейкоцитарний шар, а ще вище - плазма, збагачена тромбоцитами, над нею - 
безклітинна плазма). При одержанні PRP відбирали шприцом шар плазми над лейкоцитарним концентратом і проводили підрахунок тромбоцитів за допомогою камери Горяєва. Для кожної величини відцентрової сили використали по 5 зразків нативної крові. Статистичну обробку проводили за допомогою програми Stat POL Roms.

Для одержання щільного фібрину, збагаченого тромбоцитами, у кролів $(\mathrm{n}=25)$ відбирали кров об'ємом 5 мл у пробірки без антикоагулянту, яку відразу центрифугували протягом 10 хв на центрифузі MPW-340 (виробник Польща). Усі маніпуляції виконувалися із дотриманням правил асептики та антисептики. Використовували чотири різні величини відносної відцентрової сили: 400 g, 735 g, 906 g, 1843 g. Сформовані згустки фібрину, збагаченого тромбоцитами, відділяли від еритроцитарної маси та візуально ділили на 3 частини для подальшого дослідження: 1 межувала 3 еритроцитарною масою, 2 у центральній частині PRF, 3 - розміщувалася біля верхівки пробірки (рис. 2).

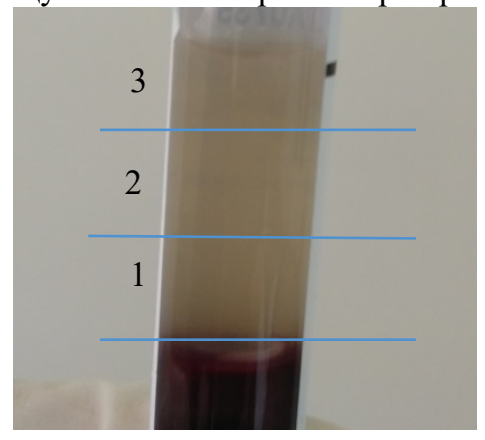

Рис. 2. 1 - нижня, 2 - центральна, 3 верхня частини згустків PRF, які використовувалися для подальшого гістологічного дослідження
Паралельно одержали ін'єкційний фібрин, збагачений тромбоцитами. 3 метою недопущення полімеризації фібрину (тобто його згортання) час центрифугування складав 3 хв, а величина відцентрової сили 100 g. Для проведення гістологічного дослідження плазму в стані полімеризації, яка розділилася на дві фракції жовту(власне I-PRF - 2/3 об'єму) та червону (межа розподілу між еритроцитами та жовтою ділянкою 1/3 об'єму) відбирали пошарово за допомогою піпетки відразу після приготування, розливали у 3 окремі пластикові пробірки для полімеризації з рідкої фракції у щільні згустки та подальшої гістологічної оцінки клітинного складу в різних шарах (нижньому, середньому і верхньому).

Згустки обох форм фібрину фіксували у $10 \%$ розчині формаліну, після чого промивали водою, зневоднювали в спиртах зростаючої концентрації та заливали у парафін, лінійкою вимірювали їхню довжину. Парафінові зрізи отримували на ротаційному мікротомі та фарбували гематоксиліном і еозином. Далі їх аналізували за допомогою мікроскопа фірми ZEISS 3 цифровим фотоапаратом Canon G5 та комп'ютерної програми Zoom Browser.

\section{Результати дослідження}

Підрахунок тромбоцитів у зразках PRP, одержаних за різних величин відносної відцентрової сили показав наступні результати (табл. 1).

\section{Таблиця 1}

Кількість тромбоцитів у плазмі, збагаченій тромбоцитами за різних величин відносної відцентрової сили

\begin{tabular}{|c|c|c|c|c|}
\hline $\begin{array}{c}\text { Відносна } \\
\text { відцентрова сила }\end{array}$ & Час центрифугування & $\begin{array}{l}\text { Кролі, } \\
\text { № п/п }\end{array}$ & $\begin{array}{c}\text { Кількість тромбоцитів } \\
\text { у PRP }\left(\times 10^{9} / л\right)\end{array}$ & $\begin{array}{c}\text { Середня кількість тромбоцитів } \\
\text { у PRP }\left(\times 10^{9} / л\right), \mathrm{M} \pm \mathrm{m}\end{array}$ \\
\hline \multirow{5}{*}{$100 \mathrm{~g}$} & \multirow{5}{*}{$3 \mathrm{xв}$} & 1 & 780 & \multirow{5}{*}{$824 \pm 30,4$} \\
\hline & & 2 & 920 & \\
\hline & & 3 & 870 & \\
\hline & & 4 & 790 & \\
\hline & & 5 & 760 & \\
\hline \multirow{5}{*}{$400 \mathrm{~g}$} & \multirow{5}{*}{10 хв } & 6 & 550 & \multirow{5}{*}{$550 \pm 21,2$} \\
\hline & & 7 & 490 & \\
\hline & & 8 & 520 & \\
\hline & & 9 & 580 & \\
\hline & & 10 & 610 & \\
\hline \multirow{5}{*}{$735 \mathrm{~g}$} & \multirow{5}{*}{10 хв } & 11 & 310 & \multirow{5}{*}{$322 \pm 18,8$} \\
\hline & & 12 & 280 & \\
\hline & & 13 & 380 & \\
\hline & & 14 & 350 & \\
\hline & & 15 & 290 & \\
\hline \multirow{5}{*}{$906 \mathrm{~g}$} & \multirow{5}{*}{10 хв } & 16 & 90 & \multirow{5}{*}{$150 \pm 23,5$} \\
\hline & & 17 & 150 & \\
\hline & & 18 & 220 & \\
\hline & & 19 & 180 & \\
\hline & & 20 & 110 & \\
\hline \multirow{5}{*}{$1843 \mathrm{~g}$} & \multirow{5}{*}{10 хв } & 21 & 30 & \multirow{5}{*}{$20 \pm 4,5$} \\
\hline & & 22 & 10 & \\
\hline & & 23 & 20 & \\
\hline & & 24 & 30 & \\
\hline & & 25 & 10 & \\
\hline
\end{tabular}

Примітка: значення $\mathrm{P}<0,001$ порівняно з попередніми параметрами центрифугування 
Зі збільшенням величини відцентрової сили від $100 \mathrm{~g}$ і до 1843 g відбувалося осідання тромбоцитів на лейкоцитарний шар, їхня кількість була щоразу вірогідно нижчою $(\mathrm{P}<0,001)$. При цьому лише випадки центрифугування за $100 \mathrm{~g}$ та $400 \mathrm{~g}$ дозволяли одержати концентрацію тромбоцитів, яка вважається достатньою для досягнення лікувальних ефектів тромбоцитарних мас. Проте вірогідно найвищою виявилася концентрація тромбоцитів у плазмі за відносної відцентрової сили $100 \mathrm{~g}$.
Застосування різних величин відцентрової сили показали очевидні відмінності у формуванні згустків фібрину, збагачених тромбоцитами (табл. 2, рис. 4). 3 підвищенням цього параметра збільшувався і об'єм утвореного біоматеріалу. Після приготування I-PRF його об'єм був значно меншим, порівняно зі стандартним PRF, а межа між еритроцитами - менш чіткою (рис. 3).
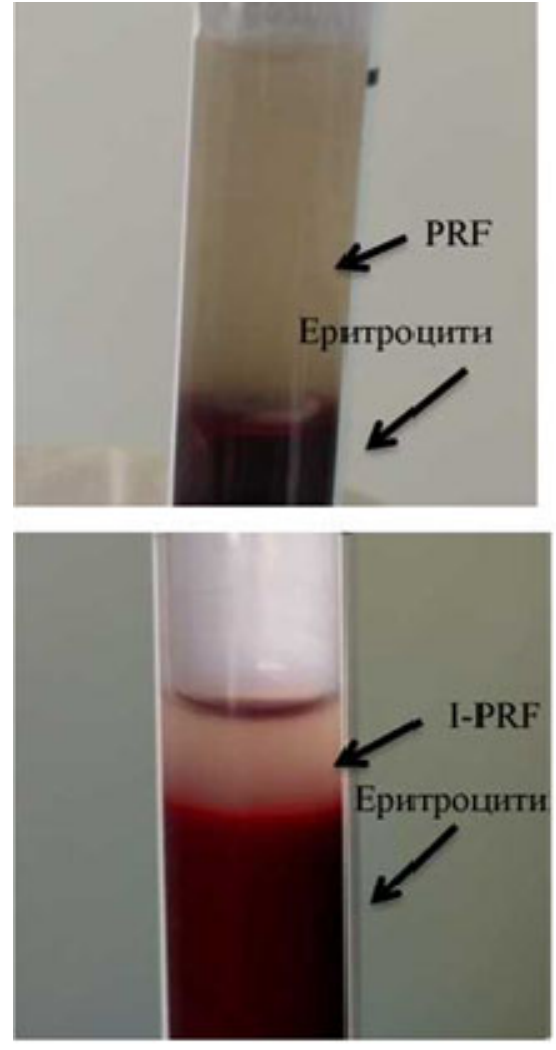

Рис. 3. Об'єми та лінійні розміри PRF та I-PRF
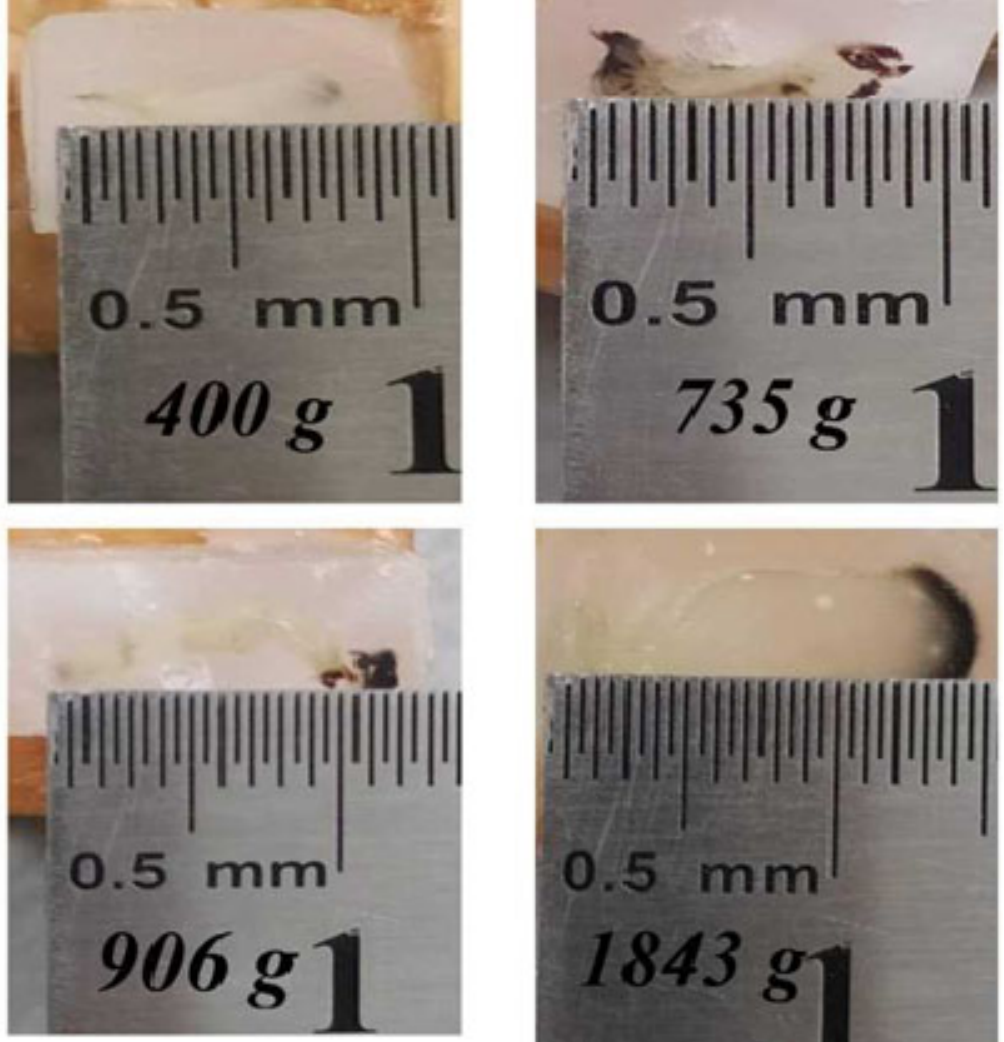

Таблиця 2

Довжина (см) згустків PRF та I-PRF за різних величин відносної відцентрової сили

\begin{tabular}{cccccc}
\hline \multirow{2}{*}{$№$ п/п } & \multicolumn{5}{c}{ Величини відносної відцентрової сили } \\
\cline { 2 - 5 } & $100 \mathrm{~g}$ & $400 \mathrm{~g}$ & $735 \mathrm{~g}$ & $906 \mathrm{~g}$ & $1843 \mathrm{~g}$ \\
\hline 1 & 0,3 & 0,8 & 0,9 & 1,2 & 1,45 \\
2 & 0,25 & 0,75 & 0,85 & 1,3 & 1,5 \\
3 & 0,34 & 0,7 & 0,95 & 1,35 & 1,4 \\
4 & 0,28 & 0,75 & 0,95 & 1,25 & 1,5 \\
5 & 0,39 & 0,85 & 1,0 & 1,3 & 1,55 \\
$\mathrm{M} \pm \mathrm{m}$ & $0,31 \pm 0,02$ & $0,77 \pm 0,03^{* *}$ & $0,93 \pm 0,03^{*}$ & $1,28 \pm 0,03^{* *}$ & $1,48 \pm 0,03^{*}$ \\
\hline
\end{tabular}

Примітка: значення $\mathrm{P}-*<0,01 ; \mathrm{P}-{ }^{* *}<0,001$, порівняно з попереднім згустком РRF, одержаним за меншої величини відносної відцентрової сили

Шляхом лінійного вимірювання PRF та I-PRF одержаних за різних режимів центрифугування було визначено, що збільшення відцентрової сили забезпечує формування згустку з вірогідно більшою довжиною, але надзвичайно низькою концентрацією тромбоцитів.

Встановлено (рис. 5), що за центрифугування крові 3 використанням відносної відцентрової сили $400 \mathrm{~g}$ лейкоцити розміщуються по всьому згустку, але їх основна маса перебуває в нижній його частині. При цьому тромбоцити розміщені в усіх ділянках практично рівномірно.

За центрифугування зразка крові при 735 g (рис. 6) переважна більшість лейкоцитів та еритроцитів розміщується в нижній частині згустку, в невеликій кількості лейкоцити містяться в центральній, а у верхній лише тромбоцити. Біля стінок пробірки у верхній частині спостерігали незначну кількість еритроцитів. 


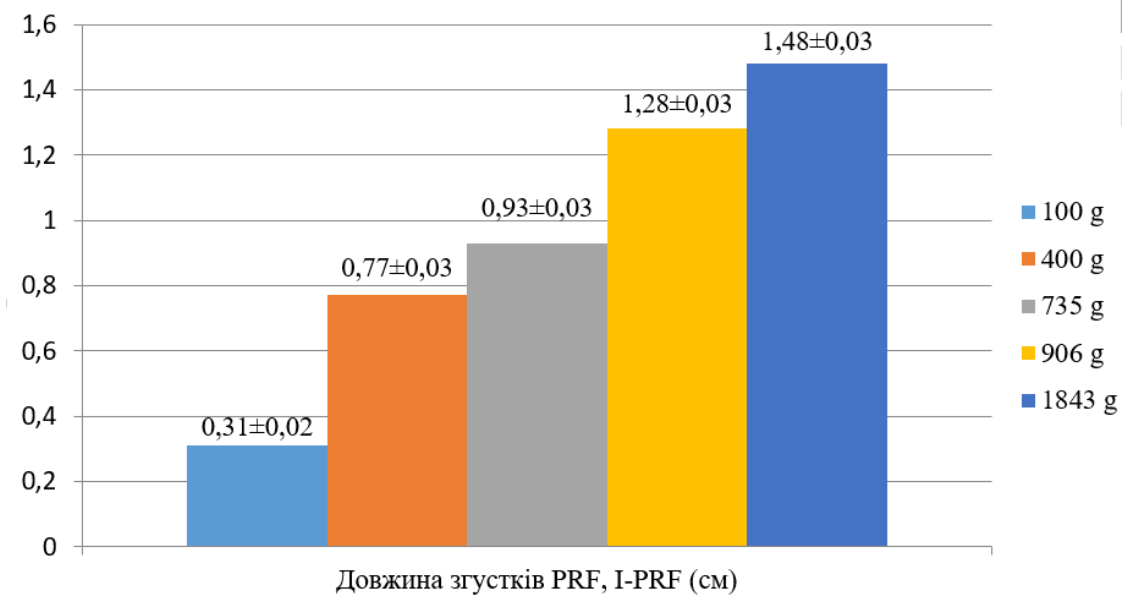

Рис. 4. Залежність довжини згустків PRF та I-PRF від величини відщентрової сили
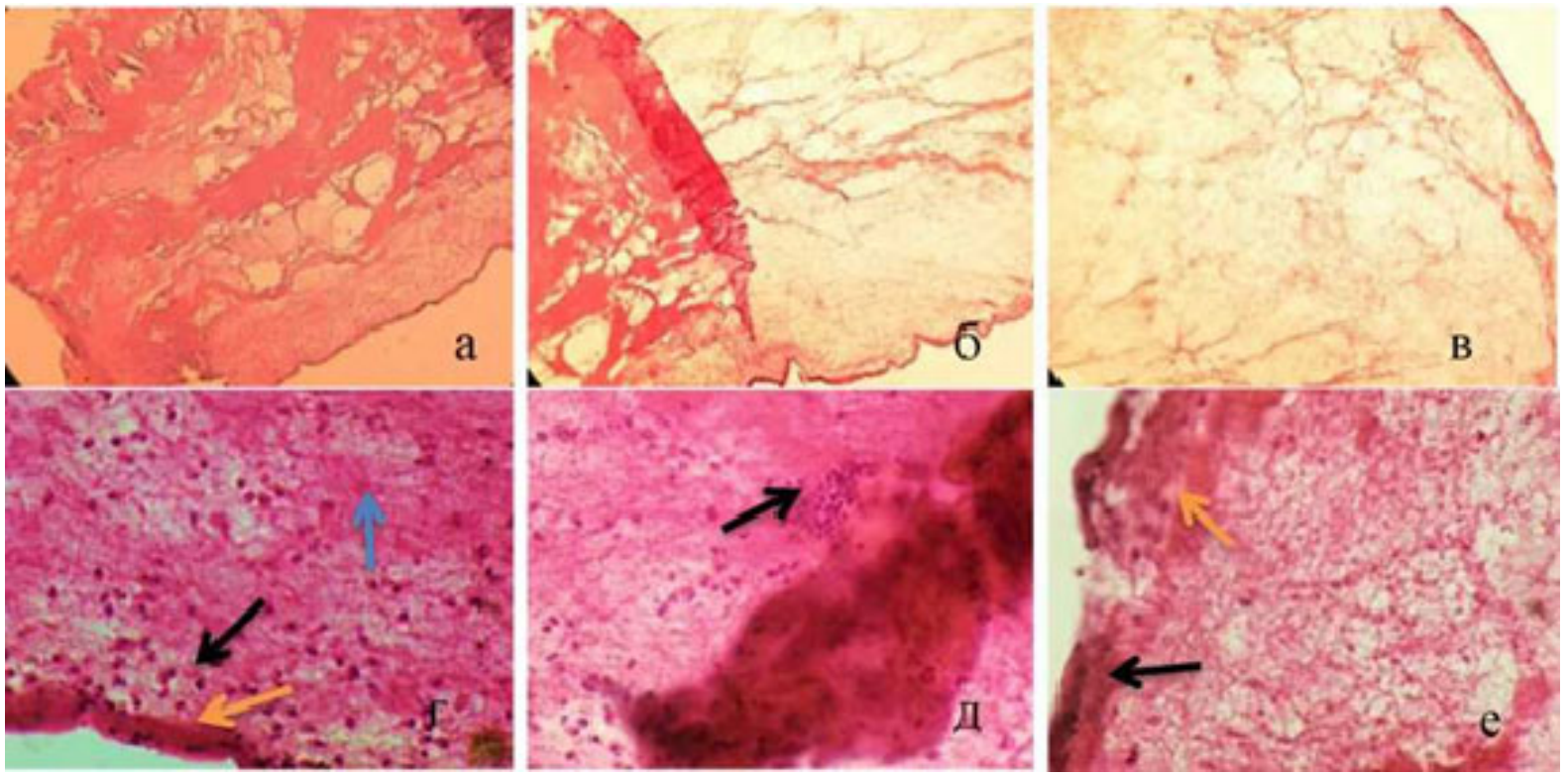

Рис. 5. Гістокартина фібринових згустків гематоксилін/еозин за $400 \mathrm{~g}$

Примітки: 1) Нижня (а), центральна (б), верхня (в) їх частини, ×100; 2) Нижня (г), центральна (д), верхня (е) їх частини, $\times 400$ (лейкоцити - чорна стрілка, скупчення тромбоцитів - синя, еритроцити - помаранчева)
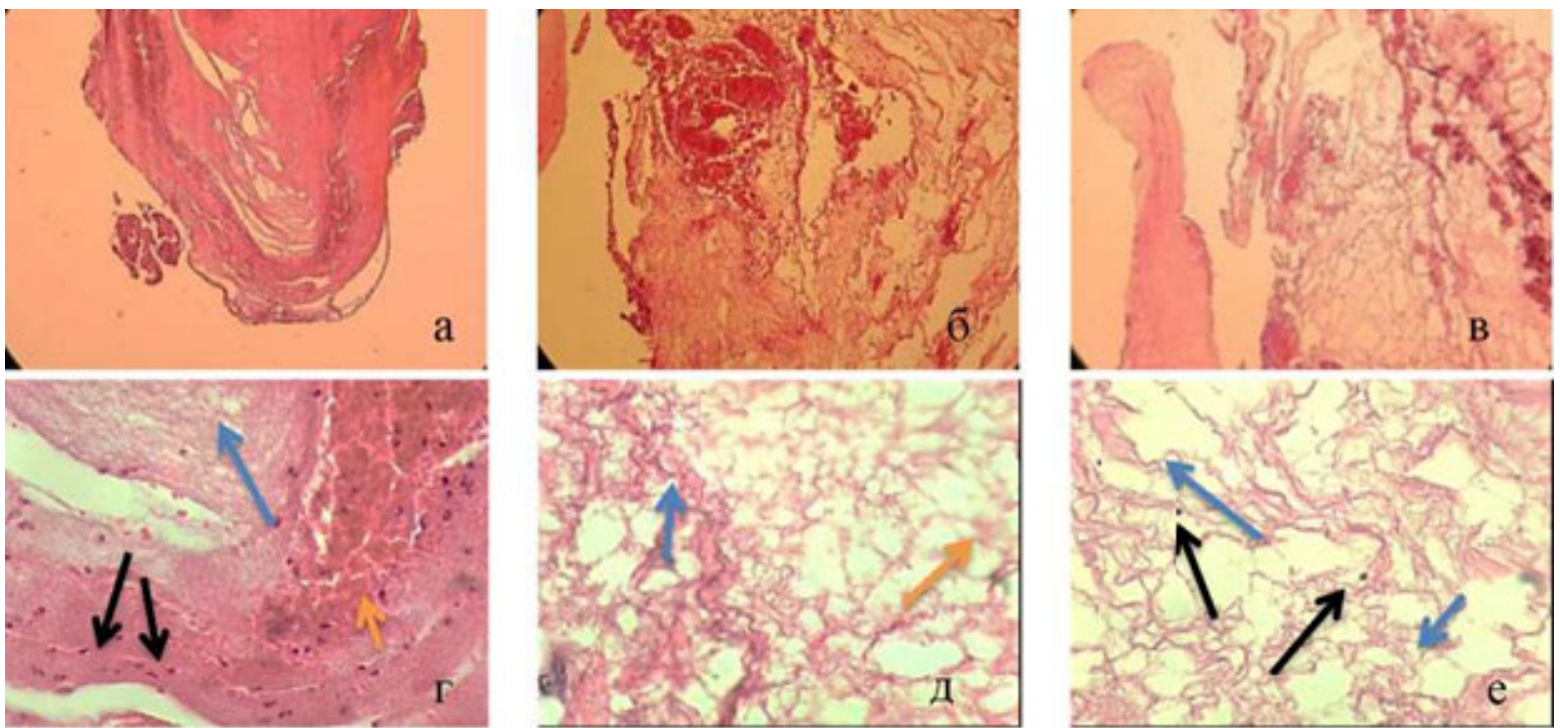

Рис. 6. Гістокартина фібринових згустків гематоксилін/еозин за $735 \mathrm{~g}$

Примітки: 1) Нижня (а), центральна (б), верхня (в) їх частини, х100; 2) Нижня (г), центральна (д), верхня (е) їх частини, $\times 400$ (лейкоцити - чорна стрілка, скупчення тромбоцитів - синя, еритроцити - помаранчева) 
За центрифугування зразка крові при 906 g (рис. 7) встановлено розміщення еритроцитів та лейкоцитів лише у нижній частині за значної кількості тромбоцитів у вигляді скупчень, а у центральній та верхній частинах згустку були скупчення тромбоцитів 3 поодинокими еритроцитами на периферії біля стінок пробірки.
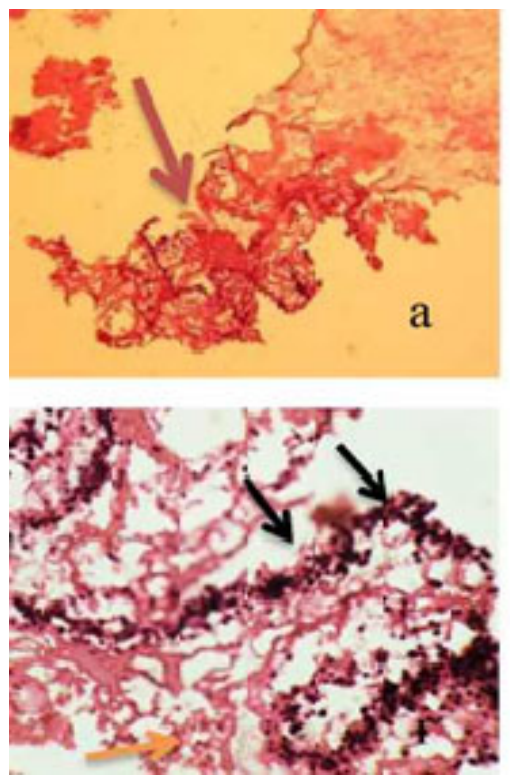

Рис. 7. Гістокартина фібринових згустків гематоксилін/еозин за $906 \mathrm{~g}$
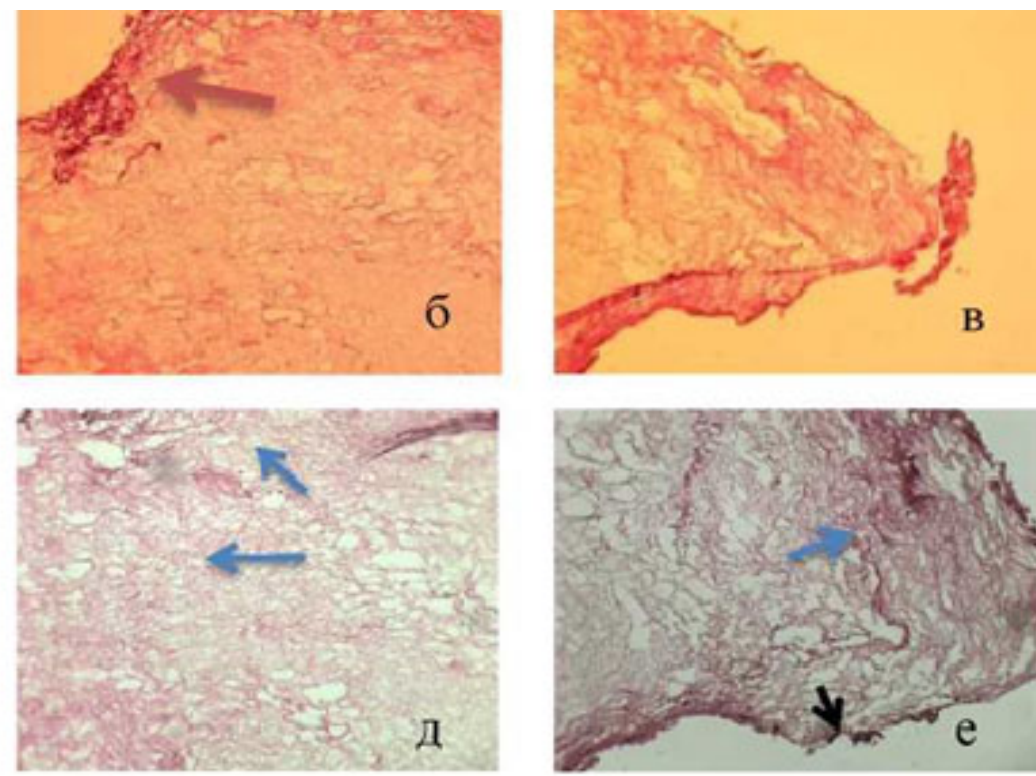

Примітки: 1) Нижня (а), центральна (б), верхня (в) їх частини, ×100; 2) Нижня (г), центральна (д), верхня (е) їх частини, $\times 400$ (лейкоцити - чорна стрілка, скупчення тромбоцитів - синя, еритроцити - помаранчева)

Під час центрифугування зразка крові з параметрами відцентрової сили 1843 g (рис. 8) в нижній частині згустку виявлено в невеликій кількості еритроцити та лейкоцити, але переважна більшість останніх зосередилася поза його межами, а саме в еритроцитарному шарі. При цьому значна кількість тромбоцитів розміщувалася майже на межі з основною масою ери- троцитів. У центральній та верхній частинах згустку містилася невелика кількість тромбоцитів у вигляді скупчень, розташованих на периферії згустку. Тобто за таких умов центрифугування основна маса тромбоцитів міститься поза межами фібринового згустку, який відповідно не має біологічних властивостей, притаманних тромбоцитам.
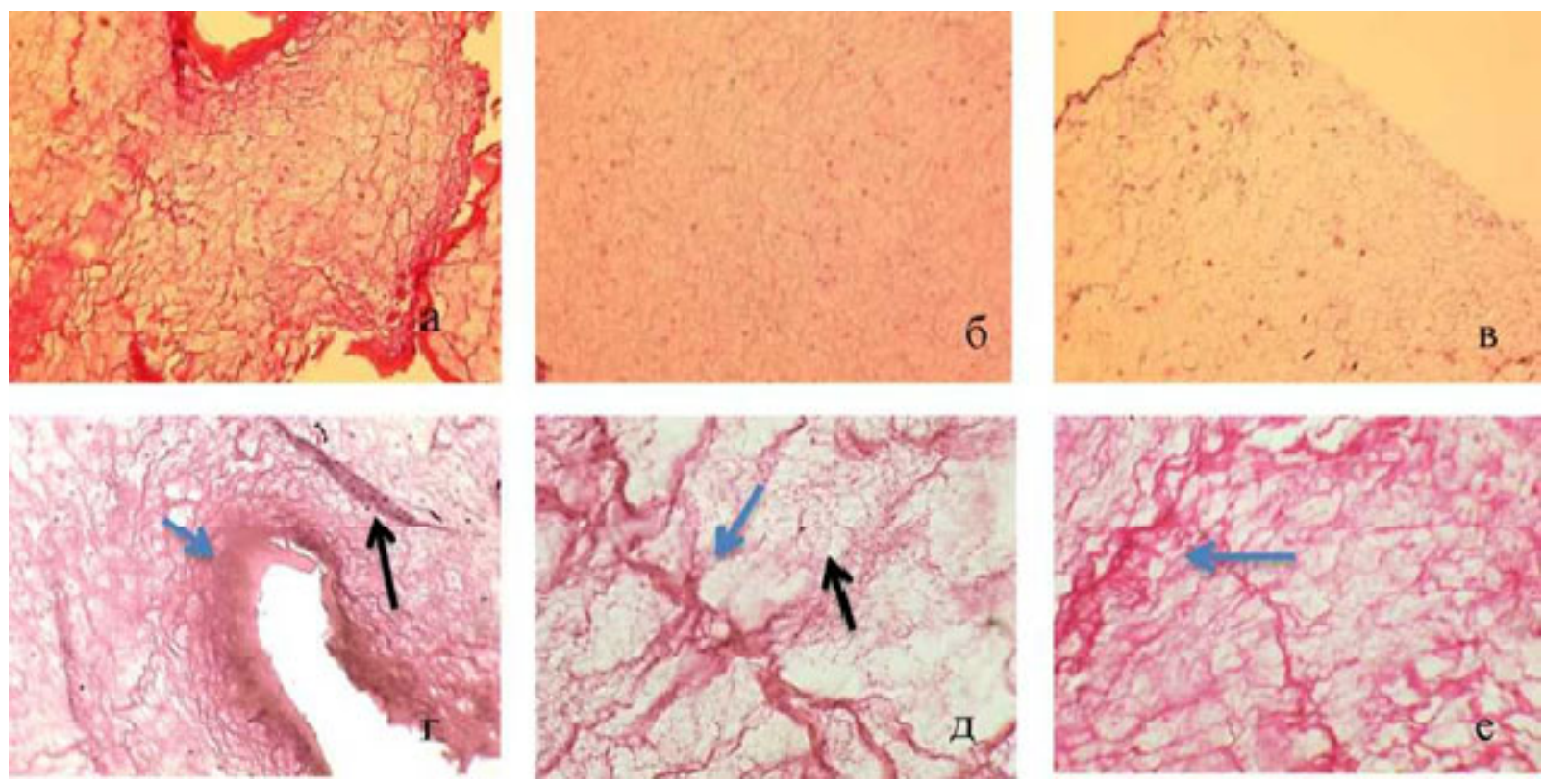

Рис. 8. Гістокартина фібринових згустків гематоксилін/еозин за $1843 \mathrm{~g}$

Примітки: 1) Нижня (а), центральна (б), верхня (в) їх частини, ×100; 2) Нижня (г), центральна (д), верхня (е) їх частини, $\times 400$ (лейкоцити - чорна стрілка, скупчення тромбоцитів - синя, еритроцити - помаранчева) 
За центрифугування 3 відносною відцентровою силою $100 \mathrm{~g}$ (рис. 9) у нижньому шарі I-PRF (червона межа розподілу) виявляли велику кількість еритроцитів, лейкоцити, які були присутні майже у всіх ділянках, а основна маса тромбоцитів у вигляді фіолетових скупчень розміщена у середньому та верхньому шарах.
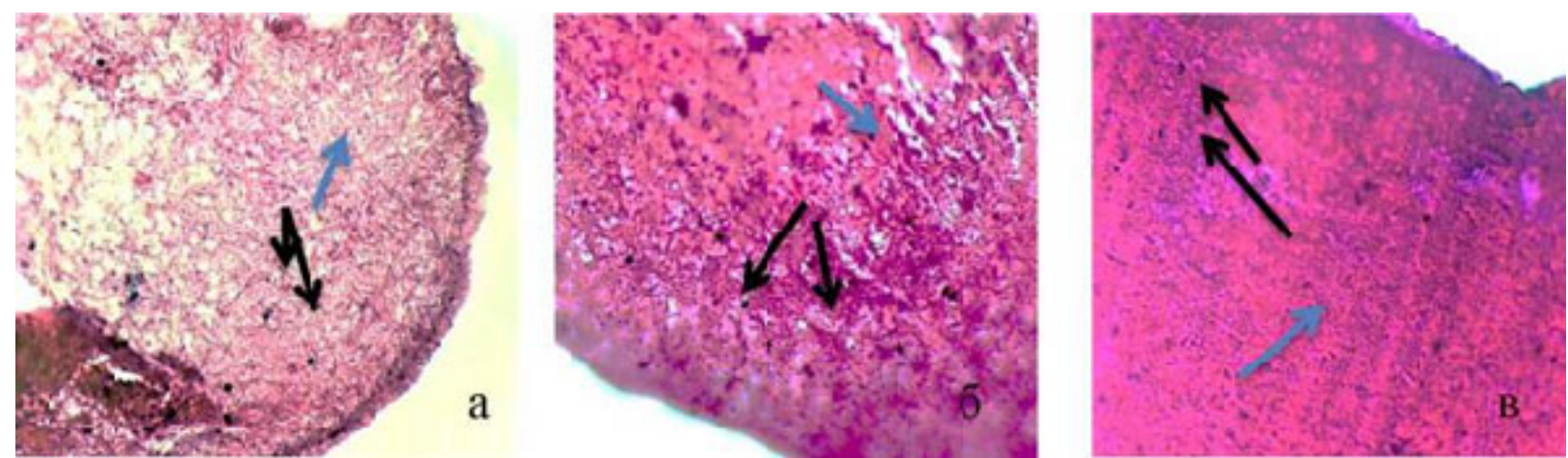

Рис. 9. Гістокартина згустків полімеризованого фібрину, збагаченого тромбоцитами, одержаного за $100 \mathrm{~g}$ гематоксилін/еозин

Примітки: 1) Нижня (а), центральна (б), верхня (в) їх частини, $\times 400$

Таким чином, при підвищенні параметра відносної відцентрової сили суттєво збільшується довжина фібринового згустку, але суттєво зменшується в ньому концентрація тромбоцитів. Тобто встановлено, що найбільш оптимальною величиною відносної відцентрової сили для отримання тромбоцитарної маси є $100 \mathrm{~g}$, що дозволяє досягти кількості тромбоцитів, більшої за 800 Г/л.

\section{Обговорення}

На початку розвитку другого покоління тромбоцитарних концентратів не надавалося особливого значення відмінностям між центрифугами, хоч це могло бути ключовим чинником у співвідношенні клітинних елементів фібрину, збагаченого тромбоцитами.

Центрифугування - це процес, який унаслідок взаємодії різних сил - гравітаційної, сили тяжіння частинок (клітин) та відцентрової сили, приводить до розподілу клітин залежно від їх розміру і маси (Choukroun \& Ghanaati, 2018).

Відомо (Kossev \& Sokolov, 2015; Öncü et al., 2016), що кількість тромбоцитів у PRP здатна впливати на репаративні процеси таким чином: стимулюючи у кількості від 800-1500 ×109/л та інгібуючи, коли цей показник перевищує $5000 \times 10^{9} /$ л.

Проведене дослідження демонструє, що PRP, одержана при $100 \mathrm{~g}$, хоч і мала доволі незначний об'єм, все ж містила необхідну кількість клітин для індукції репаративного потенціалу. Ймовірно, що PRF при отриманні його за такого ж режиму теж матиме відповідне число тромбоцитів.

Фібрин, збагачений тромбоцитами, являє собою мережу фібринових ниток, серед яких залежно від застосованої відцентрової сили у різних ділянках розташовуються еритроцити, лейкоцити та тромбоцити у вигляді скупчень. Зважаючи на те, що IPRF перебуває в рідкій формі, все ж через деякий час відбувається процес його полімеризації i перетворення у щільний згусток, схожий за зовнішнім виглядом на PRF, хоч і за меншого об'єму. Зазначимо, що в результаті аналізу гістологічних зразків, саме у цій формі 3 усіх досліджуваних речовин було виявлено найвищі концентрації лейкоцитів та тромбоцитів, які майже рівномірно розподілилися в різних шарах біоматеріалу.

Дослідження зарубіжних вчених (Ghanaati et al., 2018), які проводили визначення кількості клітин у згустках PRF (перешкоджаючи їх згортанню) за різних режимів центрифугування та визначення концентрації судинно-ендотеліального фактора росту, показали, що зі зниженням відносної відцентрової сили відбувається підвищення рівня лейкоцитів i концентрації судинного ендотеліального фактора росту (VEGF) (Ghanaati et al., 2018). Проте ці результати не веріфікують ділянок розподілу клітин у згустках.

Наведені результати дають розуміння того факту, що застосування різних ділянок згустків PRF або невеликої кількості I-PRF для регенерації однакових тканин по-різному буде впливати на репаративні процеси, оскільки його частини будуть значно відрізнятися за складом і концентрацією лейкоцитів та тромбоцитів i, як наслідок, різною концентрацією та ступенем екскреції факторів росту. Існує припущення (Lesche et al., 2016), що величина відносної відцентрової сили здатна впливати на вихід біоактивних речовин з альфа-гранул тромбоцитів.

Проте варто врахувати, що лейкоцити, які також потрапляють у I-PRF, теж $є$ джерелом VEGF та інших факторів росту (Yaltirik et al., 2018), а нейтрофіли забезпечують випуск протеаз та інших речовин, спрямованих на боротьбу зі шкідливими мікроорганізмами. Не виключено, що їх потрапляння в тканини у великій концентрації з частиною згустку фібрину, збагаченого тромбоцитами, може викликати додаткові реакції у тканинах.

У зв'язку з цим в подальшому необхідно ретельно дослідити вплив окремо взятих ділянок фібринових матриць, виготовлених за різних значень відцентрової сили (Lesche et al., 2016; Ghanaati et al., 2018) та 
залежність клітинного співвідношення у них на різні типи тканин. Після чого, можливо, адаптувати протоколи PRF для оптимізації репатативних процесів у різних тканинах.

\section{Висновки}

1. Різні величини відносної відцентрової сили центрифугування крові та його час суттєво впливають на розподіл клітинних елементів у згустках фібрину. Ії зниження зумовлює збільшення кількості не лише тромбоцитів, а й лейкоцитів 3 утворенням меншого об'єму аутологічного PRF. Скорочення часу центрифугування до 3 хв дає змогу одержати рідку форму фібрину, збагачену тромбоцитами.

2. За умов центрифугування при 100 g у I-PRF концентрація тромбоцитів і лейкоцитів досягає максимального рівня 3 майже рівномірним розподілом клітин у фібриновому згустку.

3. Перспектива подальших досліджень полягає в оцінці впливу PRF та I-PRF з різною концентрацією і складом клітин на регенерацію різних типів тканин.

Конфлікт інтересів. Представлені дослідження виконані відповідно до затвердженої теми дисертаційної роботи "Застосування гідроксиапатитних композитів 3 фібрином, збагаченим тромбоцитами, за кісткової патології опорно-рухового апарату в тварин” (протокол № 4 від 13 грудня 2018 р.) та виконання Держбюджетної тематики “Доклінічні дослідження виробів зі зроблених біоматеріалів” № 48/1 від 27. 08. 2019) в рамках виконання науководослідної роботи “Розробка та доведення до впровадження в клінічну практику кісткових імплантів різного призначення з новітніх біоматеріалів для відновлення кісткової тканини та функції кісток після поранень в бойових діях" (Договір № 515 від 17 квітня 2019 р.) відповідно до цільової науково-технічної програми НАН України “Дослідження і розробки 3 проблем підвищення обороноздатності і безпеки держави" та розпорядження НАН України від 16.04.2019 № 255 .

\section{References}

Arora, S., \& Agnihotri, N. (2017). Platelet Derived Biomaterials for Therapeutic Use: Review of Technical Aspects. Indian J Hematol Blood Transfus, 33(2), 159-167. doi: 10.1007/s12288-016-0669-8.

Ayswaria, B., Sarath, C., \& Seema, G. (2018). An Overview of Platelet Rich Fibrin in Periodontal Therapy. Journal of Indian Dental Association Attingal Branch, 8(2), 49-53.

Bansal, S., Garg, A., Khurana, R., \& Chhabra, P. (2017). Platelet-rich fbrin or platelet-rich plasma - Which one is better? An opinion. Indian J Dent Sci, 9(5), 49-52. doi: 10.4103/IJDS.IJDS 5517.

Bielecki, T., \& Dohan Ehrenfest, D. M. (2012). PlateletRich Plasma (PRP) and Platelet-Rich Fibrin (PRF): Surgical Adjuvants, Preparations for In Situ Regenerative Medicine and Tools for Tissue
Engineering. Current Pharmaceutical Biotechnology, 13(7), 1121-1130. doi: 10.2174/138920112800624292.

Chernyshenko, V., Steinberg, K., Lugovska, N., Ryzhykova, M., Platonova, T., Korolova', D., \& Lugovskoy, E. (2019). Preparation of higlyconcentrated autologus piatelet-rich plasma for biomedical use. Ukr. Biochem. J., 91(2), 19-27. doi: 10.15407/ubj91.02.019.

Chicharro, D., Carrillo, J. M., Rubio, M., Cugat, R. et al. (2018). Combined plasma rich in growth factors and adipose-derived mesenchymal stem cells promotes the cutaneous wound healing in rabbits. BMC Veterinary Research, 14, 288. doi: 10.1186/s12917-018-1577-y.

Choukroun, J., \& Ghanaati, S. (2018). Reduction of relative centrifugation force within injectable plateletrich-fbrin (PRF) concentrates advances patients' own inflammatory cells, platelets and growth factors: the first introduction to the low speed centrifugation concept. Eur J Trauma Emerg Surg, 44, 87-95. doi: 10.1007/s00068-017-0767-9.

Davenport Huyer, L., Pascual-Gil, S., Wang, Y., Mandla, S., Yee, B., \& Radisic, M. (2020). Advanced Strategies for Modulation of the MaterialMacrophage Interface. Adv. Funct. Mater, 30(44), 1909331. doi: 10.1002/adfm.201909331.

de Almeida, V. H., de Araujo, R. F., Vasconcelos, R. C., Garcia, V. B., de Souza, L. B., \& de Araujo, A. A. (2018). Histological Preparation Technique of Blood Derivative Injectable Platelet-Rich Fibrin (I-Prf) for Microscopic Analyzes. J Cytol Histol, 9(3). 1000506. doi: 10.4172/2157-7099.1000506.

De Pascale, M. R., Sommese, L., Casamassimi, A., \& Napoli, C. (2015). Platelet Derivatives in Regenerative Medicine: An Update. Transfusion Medicine Reviews, 29, 52-61. doi: 10.1016/j.tmrv.2014.11.001.

Dohan Ehrenfest, D. M., Bielecki, T., Mishra, A., Borzini, P. et al. (2012). In Search of a Consensus Terminology in the Field of Platelet Concentrates for Surgical Use: Platelet-Rich Plasma (PRP), PlateletRich Fibrin (PRF), Fibrin Gel Polymerization and Leukocytes. Current Pharmaceutical Biotechnology, 12, 1131-1137.

Dohan Ehrenfest, D. M., Rasmusson, L., \& Albrektsson, T. (2009). Classification of platelet concentrates: from pure platelet-rich plasma (P-PRP) to leucocyte- and platelet-rich fibrin (L-PRF). Trends in Biotechnology, 27(3), 158-167. doi: 10.1016/j.tibtech.2008.11.009.

Dohan, D. M., Choukroun, J., Diss, A., Dohan, S. L. et al. (2006). Platelet-rich fibrin (PRF): A secondgeneration platelet concentrate. Part I: Technological concepts and evolution. Oral Surg Oral Med Oral Pathol Oral Radiol Endod, 101, 37-44.

Douglas, T. E. L., Vandrovcová, M., \& Kročilová, N. (2018). Application of whey protein isolate in bone regeneration: Effects on growth and osteogenic differentiation of bone-forming cells. Journal of Dairy Science, 101(1), 28-36. doi: 10.3168/jds.2017-13119.

Etulain, J. (2018). Platelets in wound healing and regenerative medicine. Platelets, 29(6), 556-568. doi: 10.1080/09537104.2018.1430357. 
Franklin, S. P., Birdwhistell, K. E., \& Strelchik, A. (2017). Influence of Cellular composition and Exogenous Activation of Growth Factor and Cytokine Concentrations in Canine Platelet-Rich Plasmas. Frontiers in Veterinary Science, 4, 40. doi: 10.3389/fvets.2017.00040.

Ghanaati, S., Al-Maawi, S., Herrera-Vizcaino, C., Alves, G.G., Calasans-Maia, M.D., Sader, R., Kirkpatrick, C.J., Choukroun, J., Bonig, H., \& Mourão, C. F. A. B. (2018). A proof of the low speed centrifugation concept in rodents: new perspectives for in vivo research. Tissue Engineering Part C: Methods, 24(11), 659-670. doi: 10.1089/ten.TEC.2018.0236.

Gillman, N., Lloyd, D., Bindra, R., Ruan, R., \& Zheng, M. (2020). Surgical applications of intracorporal tissue adhesive agents: current evidence and future Development. Expert Review of Medical Devices, 17(5), 443-460. doi: 10.1080/17434440.2020.1743682.

Khalaf, F. H., \& Salih, S. I. (2018). Clinical and histopathological evaluation of using platelet-rich plasma and platelet-rich fibrin matrix in treatment of induced chronic open wounds in bucks. Asian Journal of Pharmaceutical and Clinical Research, 11(5), 337341. doi: 10.22159/ajpcr.2018.v11i5.24105.

Kiran, N. K., Mukunda, K. S., \& Tilak Raj, T. N. (2011). Platelet Concentrates: A Promising Innovation In Dentistry. Journal of Dental Sciences \& Research, 2(1), 50-61.

Kossev, P., \& Sokolov, T. (2015). Platelet-rich Plasma (PRP) in Orthopedics and Traumatology - Review. Immunopathology and Immunomodulation, 173-195. doi: $10.5772 / 61326$.

Lesche, D., Geyer, R., Lienhard, D., Nakas, C. T., Diserens, G., Vermathen, P., \& Leichtle, A. B. (2016). Does centrifugation matter? Centrifugal force and spinning time alter the plasma metabolome. Metabolomics, 12, 159. doi: 10.1007/s11306-016-1109-3.

Maia, F. R., Correlo, V. M., Oliveira, J. M., \& Reis, R. L. (2019). Chapter 32- Natural Origin Materials for Bone Tissue Engineering: Properties, Processing, and Performance. Principles of Regenerative Medicine (Third Edition), Academic Press, 2019, 535-558. doi: 10.1016/B978-0-12-809880-6.00032-1.

Öncü, E., Bayram, B., Kantarc1, A., Gülsever, S., \& Alaaddinoğlu, E. E. (2016). Positıve effect of platelet rich fbrin on osseointegration. Med Oral Patol Oral Cir Bucal, 21(5), e601-e607. doi: 10.4317/medoral.21026.

Oryan, A., Alidadi, S., Moshiri, A., \& Bigham-Sadegh, A. (2014). Bone morphogenetic proteins: A powerful osteoinductive compound with non-negligible side effects and limitations. International Union of Biochemistry and Molecular Biology, 40(5), 459-481. doi: 10.1002/biof.1177.

Pazzini, J. M., De Nardi, A. B. Huppes, R. R., \& Gering, A. P. (2016). Method to obtain platelet-rich plasma from rabbits. Pesq. Vet. Bras., 36(1), 39-44. doi: 10.1590/S0100-736X2016000100007.

Peck, M. T., Hiss, D., \& Stephen, L. (2016). Factors affecting the preparation, constituents, and clinical effcacy of leukocyte- and platelet- rich fibrin (L-PRF). SADJ, 71(7), 298-302.

Rublenko, M. V., Andriec', V. G., Lugovs'koj, E. V., Platonova, T. M., \& Chernishenko, T. M. (2014). Kliniko-rentgenologichna harakteristika eksperimental'nogo zastosuvannja fibrinovogo gelju dlja optimizaciï reparativnogo osteogenezu v kroliv. Naukovij visnik veterinarnoï medicini, 14(114), 130134 (in Russian).

Shevchenko, S., Rublenko, M., \& Bonkovsky, O. (2019). Technologies for producing platelet masses for regenerative medicine. Naukovij visnyk veterinarnoi medycyny, 2, 105-117. doi: 10.33245/2310-49022019-152-2-105-117.

Thanasrisuebwong, P., Surarit, R., Bencharit, S., \& Ruangsawasdi, N. (2019). Influence of Fractionation Methods on Physical and Biological Properties of Injectable Platelet-Rich Fibrin: An Exploratory Study. $\begin{array}{llll}\text { Int. J. } & \text { Mol. }\end{array}$ doi: 10.3390/ijms20071657.

Tina Roshini, S., Arunprasad, A., Justin William, B., Jeyaraja, K., \& Priyadharshini, K. (2019). Autologous platelet rich plasma for regeneration of tendon injuries in horses. Indian journal of animal researc, 2019(53), 1354-1360. doi: 10.18805/ijar.B-3653.

Wang, X., Zhang, Y., Choukroun, J., Ghanaati, S. et al. (2017). Behavior of Gingival Fibroblasts on Titanium Implant Surfaces in Combination with either InjectablePRF or PRP. International Journal of Molecular Sciences, 18(2), 331. doi: 10.3390/ijms18020331.

Yaltirik, M., Koray, M., Kocaelli, H., \& Ofluoglu, D. (2018). Platelet-Rich Plasma in Trauma Patients. Trauma in Dentistry. doi: 10.5772/intechopen.79966.

Zhang, Y., Tangl, S., Huber, C. D., Lin, Y. et al. (2012). Effects of Choukrouns platelet-rich fibrin on bone regeneration in combination with deproteinized bovine bone mineral in maxillary sinus augmentation: A histological and histomorphometric study. Journal of Cranio-Maxillo-Facial Surgery, 40(4), 321-328. doi: 10.1016/j.jcms.2011.04.020. 